\title{
Wpływ doświadczeń II wojny światowej na kierunki rozwoju i organizacji Wojska Polskiego w nowej rzeczywistości społeczno-politycznej (konsekwencje społeczne, polityczne i gospodarcze)
}

W

dniach 6-8 maja 2015 r. w Węgorzewie odbyła się konferencja „Wpływ doświadczeń II wojny światowej na kierunki rozwoju i organizacji Wojska Polskiego w nowej rzeczywistości społeczno-politycznej (konsekwencje społeczne, polityczne i gospodarcze)". Organizatorem były: Zakład Historii XX wieku Instytutu Historii i Stosunków Międzynarodowych Wydziału Humanistycznego Uniwersytetu Warmińsko-Mazurskiego w Olsztynie, Naukowe Koło Historyków Wojskowości, Muzeum Wojsk Lądowych w Bydgoszczy, Towarzystwo Przyjaciół 1 Mazurskiej Brygady Artylerii im. Gen. Józefa Bema, 16. Pomorska Dywizja Zmechanizowana im. Króla Kazimierza Jagiellończyka w Elblagu oraz 11. Pułk Artylerii im. gen. Józefa Bema w Węgorzewie.

Konferencję przygotowali pracownicy Instytutu Historii i Stosunków Międzynarodowych Wydziału Humanistycznego Uniwersytetu Warmińsko-Mazurskiego w Olsztynie oraz Muzeum Wojsk Lądowych w Bydgoszczy: dr hab. Wiesław Bolesław Łach, dr hab. Dariusz Radziwiłłowicz, dr hab. Halina Łach, dr Mirosław Giętkowski oraz mgr Aleksander Iwaniuk. Do Komitetu Naukowego zaproszono: prof. dr. hab. Karola Olejnika przewodniczącego, prof. dr. hab. Jerzego Będźmirowskiego, prof. dr. hab. Wojciecha Włodarkiewicza, prof. dr. hab. Lecha Wyszczelskiego, płk. dr. hab. Tadeusza Szczurka, prof. WAT oraz dr. hab. Zygmunta Matuszaka, prof. UJK. 
Inspiracją do spotkania była 70 rocznica zakończenia II wojny światowej, która niezmiennie skłania do pogłębionej refleksji nad jej genezą, przebiegiem, a zwłaszcza nad konsekwencjami tych największych w dziejach ludzkości działań zbrojnych. W założeniach przyjętych przez organizatorów celem naukowego spotkania było przedstawienie najnowszych ustaleń badawczych w tym zakresie w ujęciu interdyscyplinarnym. Jak pisali organizatorzy w zaproszeniu, ,II wojna światowa to [...] hekatomba, która w sposób niespotykany wstrząsnęła podstawami ludzkiej cywilizacji. Pokolenia powojenne żyją w jej cieniu i ciągle próbują w mniejszym lub większym stopniu wrócić do równowagi duchowej i zasad humanizmu sprzed »czasu pogardy«. Dlatego też badania historii II wojny światowej są ze wszech miar ważne i konieczne".

W swoim założeniu miała to być konferencja historyków wojskowości. Badania nad tym konfliktem zbrojnym przybierają jednak w coraz większym stopniu interdyscyplinarny charakter, gdyż zagadnienie to absorbuje już nie tylko badaczy dziejów. Dlatego na podkreślenie zasługuje fakt, że organizatorom udało się ten niejako monolit naukowy „rozsadzić”, zapraszając do udziału również naukowców niehistoryków. W efekcie w trakcie obrad głos zabierała reprezentacja politologów, filologów, kulturoznawców, filozofów i żołnierzy. Wśród uczestników konferencji z różnych krajowych ośrodków akademickich znaleźli się naukowcy instytucji wojskowych, w tym: Akademii Marynarki Wojennej w Gdyni, Wojskowej Akademii Technicznej w Warszawie i Muzeum Wojsk Lądowych w Bydgoszczy. Reprezentowany był również Instytut Pamięci Narodowej oraz jednostki archiwalne. Czynny głos zabrali oficerowie 16. Pomorskiej Dywizji Zmechanizowanej im. Króla Kazimierza Jagiellończyka wraz z szefem jej artylerii - płk. Jarosławem Gołembskim.

Przedmiotem rozważań konferencji były m.in. kwestie sztuki wojennej II wojny światowej; wpływu działań tego konfliktu zbrojnego na kierunki rozwoju taktyki, operacji i strategii; kierunku rozwoju rodzajów wojsk i broni; powojennej kadry Wojska Polskiego i jego struktur; ochrony granic; wpływu ideologii na funkcjonowanie Wojska Polskiego; represji wobec powojennej kadry Wojska Polskiego; stosunku społeczeństwa do „ludowego" Wojska Polskiego; udziału Wojska Polskiego w akcjach polityczno-propagandowych, a także zwalczania niepodległościowego podziemia. Pochylono się również nad problematyką używania symboliki i tradycji Wojska Polskiego w kreowaniu postaw żołnierza „nowej” socjalistycznej Polski. Trzydniowe obrady zostały podzielone na trzy tematyczne obszary dyskusyjne. 
Otwarcie konferencji nastąpiło 6 maja w sali konferencyjnej Ośrodka Wypoczynkowego Góra Wiatrów. Referat wprowadzający wygłosił prorektor ds. wojskowych Wojskowej Akademii Technicznej płk dr hab. Tadeusz Szczurek, prof. WAT. Tematem był interdyscyplinarny wymiar badań nad zjawiskiem wojny. Po inauguracji konferencji nastąpiła część robocza, w której tezy dyskusyjne przewidziane w sesji obszaru I grupowały wypowiedzi związane z wybraną problematyką Wojska Polskiego w II wojnie światowej. O doświadczeniach udziału kobiet na frontach II wojny światowej w świetle wybranych pamiętników i wspomnień przechowywanych w Instytucie J. Piłsudskiego w Londynie mówiły dr Aneta Niewęgłowska i dr Małgorzata Wiśniewska z Uniwersytetu Przyrodniczo-Humanistycznego w Siedlcach. Z kolei dr Rafał Roguski z tego ośrodka akademickiego dotknął doświadczeń z działalności Służby Sprawiedliwości Polskich Sił Zbrojnych na Zachodzie do zakończenia II wojny światowej. Magister Tomasz Gliniecki ukazał dylematy badawcze polskich historyków wojskowości wobec sowieckich mitów wyzwoleńczych na podstawie opisów tzw. rajdu Diaczenki przez Elbląg z 23 stycznia 1945 r., a dr Karol Sacewicz z Instytutu Pamięci Narodowej w Olsztynie podjął wyzwanie scharakteryzowania relacji Polski Podziemnej wobec ludowego Wojska Polskiego (1943-1945). Niejako kontynuacją tego tematu były rozważania dr. hab. Dariusza Radziwiłłowicza reprezentującego Uniwersytet Warmińsko-Mazurski w Olsztynie, który pokazał, jak po II wojnie światowej komuniści podjęli wysiłek kształtowania umysłów żołnierskich dzięki zmanipulowaniu tradycji oręża polskiego. Kolejny mówca - dr Adam Ostanek z Wojskowej Akademii Technicznej - odniósł się do roli Wojska Polskiego w zachowaniu bezpieczeństwa wewnętrznego Polski na przykładzie Akcji „Wisła”. Ostatnim mówcą był dr Radosław Gross z Uniwersytetu Warmińsko-Mazurskiego w Olsztynie, który zajął się wpływem doświadczeń II wojny światowej na kreowanie postaw przyszłych żołnierzy „nowej" Polski w okresie stalinowskim. Ten szeroki temat omówiony został na przykładzie paramilitarnych organizacji młodzieżowych tamtego okresu. Ostatni trzej prelegenci wprowadzili zebranych w II obszar dyskusyjny konferencji, w którym omawiano wpływ doświadczeń II wojny światowej na przemiany organizacyjne i doktrynalne Wojska Polskiego. Merytoryczne spotkanie pierwszego dnia zakończyła ożywiona dyskusja, która toczyła się do późnych godzin wieczornych.

Drugi dzień obrad odbywał się w Klubie Żołnierskim 11. Mazurskiego Pułku Artylerii im gen. Józefa Bema w Węgorzewie. Skierowany był do żołnierzy, młodzieży i mieszkańców Węgorzewa. Obrady konstytuowały się tematycznie w II obszarze dyskusyjnym. Po wprowadzeniu, które do 
tej części spotkania wygłosił prof. dr hab. Karol Olejnik, głos zabrał prof. dr hab. Lech Wyszczelski z Uniwersytetu Przyrodniczo-Humanistycznego w Siedlcach. Ten wybitny badacz historii wojskowości zajął się wpływem doświadczeń II wojny światowej na sztukę wojenną lat 40. i 50. XX w. Z kolei dr hab. Halina Łach z Uniwersytetu Warmińsko-Mazurskiego w Olsztynie scharakteryzowała kwestie organizacji, kształt i charakter Wojska Polskiego w II połowie XX w. Niejako w nawiązaniu do wypowiedzi prof. Wyszczelskiego, dr hab. Zygmunt Matuszak z Uniwersytet Jana Kochanowskiego w Kielcach (filia w Piotrkowie Trybunalskim) podjął się analizy wpływu doświadczeń II wojny światowej na rozwój sztuki wojennej Wojska Polskiego po 1945 r. Ten wątek zakończyli reprezentanci Akademii Marynarki Wojennej w Gdyni: dr Andrzej Drzewiecki, który omówił wpływ doświadczeń wojennych na rozwój Marynarki Wojennej w Polsce po 1945 r.. oraz prof. dr hab. Jerzy Będźmirowski, który ukazał uwarunkowania międzynarodowe funkcjonowania Marynarki Wojennej jako ważnego komponentu bezpieczeństwa morskiego Polski w latach 1945-1991 w odniesieniu do okresu międzywojennego.

Po krótkiej przerwie kawowej obrady wznowiono wystąpieniem prof. dr. hab. inż. Andrzeja Piętaka z Uniwersytetu Warmińsko-Mazurskiego w Olsztynie, który podjął rozważania o uwarunkowaniach rozwoju polskiej broni pancernej po II wojnie światowej. Z kolei dr Józef Zieliński z kwartalnika „Bellona” omówił wpływ doświadczeń II wojny światowej na rozwój powojennych polskich sił powietrznych. Doskonałym uzupełnieniem tej problematyki była wypowiedź dr. Łukasza Nadolskiego z Muzeum Wojsk Lądowych w Bydgoszczy, który scharakteryzował wykorzystanie doświadczeń z działań powietrznych II wojny światowej w konfliktach zbrojnych po 1945 r. Doktor Robert Kempa z Giżycka szczegółowo omówił doktrynę pionowego oskrzydlenia w kontekście użycia na współczesnym polu walki wojsk aeromobilnych. Tę część obrad zakończył dr Piotr Kardela z Instytutu Pamięci Narodowej, Delegatura w Olsztynie, który ukazał poglądy Stowarzyszenia Polskich Kombatantów w Stanach Zjednoczonych wobec ludowego Wojska Polskiego.

Trzecią część obrad tego dnia rozpoczął kmdr por. dr Jarosław Kroplewski z Dowództwa Generalnego Rodzajów Sił Zbrojnych, podejmując próbę scharakteryzowania udział aparatu politycznego Marynarki Wojennej w procesie indoktrynacji komunistycznej jej personelu w latach 1949-1956. Z kolei dr hab. Jerzy Prochwicz, reprezentujący Uniwersytet Jana Kochanowskiego w Kielcach (filia w Piotrkowie Trybunalskim), omówił polskie próby rewizji granicy zachodniej Rzeczypospolitej w latach 1945-1947, a dr Ireneusz Bieniecki z Akademii Pomorskiej w Słupsku 
przedstawił udział żołnierzy jednostek ochraniających granicę PRL w akcjach społecznych, politycznych i pracach na rzecz gospodarki narodowej w drugiej połowie XX w. Obrady zakończyli przedstawiciele Akademii Marynarki Wojennej w Gdyni. Autor niniejszego sprawozdania odniósł się w swojej wypowiedzi do historii Półwyspu Helskiego w latach 1945-1965 w jego aspektach militarnych, a dr Wojciech Mazurek omówił wykorzystanie doświadczeń II wojny światowej na rozwój sił desantowych układu warszawskiego na Bałtyku w latach 1955-1991. Zwieńczeniem części merytorycznej dnia była dyskusja, którą w sposób naturalny kontynuowano podczas indywidualnych spotkań w miejscu odpoczynku.

Ostatni dzień obrad - 8 maja - odbywał się ponownie w sali konferencyjnej Ośrodka Wypoczynkowego Góra Wiatrów w Trygorcie. Założony do rozważań III obszar dyskusyjny skupiał się na wybranych zagadnieniach działań i aktywności Wojska Polskiego. Jako pierwsi zabrali głos przedstawiciele Uniwersytetu Warmińsko-Mazurskiego w Olsztynie. Tematem wystąpienia filologa prof. dr. hab. Zbigniewa Chojnowskiego był poetycki mit bitwy pod Studziankami w twórczości Jerzego Zagórskiego. Z kolei dr hab. Zbigniew Anculewicz omówił powojenne miesiące 1945 r. w świetle opinii redakcji „Życia Warszawy”, a dr hab. Wiesław Bolesław Łach problemy Wojska Polskiego z powojennym wykorzystaniem obszaru byłych Prus Wschodnich. Kolejne głosy należały do przedstawicieli archiwistyki. Doktor Tomasz Matuszak z Archiwum Państwowego w Piotrkowie Trybunalskim zajął się miejscem, rolą i zadaniami Centralnego Archiwum Wojskowego w strukturach Wojska Polskiego po 1945 r., a mgr Maciej Hubka - kulturowymi reminiscencjami II wojny światowej w obszarze ,historii ożywionej”. Archiwum Państwowe w Olsztynie reprezentował z kolei dr Sławomir Jan Maksymowicz, który przedstawił zawiłe losy płk. pilota Bernarda Antoniego Adameckiego, oficera Polski Podziemnej, komendanta Wojskowej Szkoły Technicznej w Börnerowie, który stracił życie w 1952 r. jako ofiara stalinowskich represji. W tej części na uwagę zasługiwały wypowiedzi dwóch doktorantów Wydziału Humanistycznego Uniwersytetu Warmińsko-Mazurskiego w Olsztynie. Magister Piotr Bojarski omówił kwestie kształtowania się administracji wojskowej po II wojnie światowej w województwie olsztyńskim, a mgr Grzegorz Kała w interesujący sposób przedstawił, jak pokazywano Polskie Siły Zbrojne na Zachodzie na łamach biuletynów i innych materiałów Polskiej Agencji Prasowej „Polpress”. Ostatnim głosem konferencji była dr Monika Ziniewicz reprezentująca Uniwersytet Warmińsko-Mazurski w Olsztynie, która omówiła problematykę przejęcia i wykorzystania poniemieckiej infrastruktury na Mazurach po II wojnie światowej. 
Podsumował konferencję nestor historyków wojskowości - prof. Karol Olejnik. Interesującą wykładnię dotychczasowej wymiany myśli o efektach II wojny światowej dał również prof. dr hab. Lech Wyszczelski. Wszyscy uczestnicy byli zgodni, że od wydarzeń II wojny światowej dzieli obecne pokolenia 70 lat $\mathrm{i}$ - jak się mogłoby wydawać - dystans dwóch generacji powinien wystarczyć na wypracowanie oceny jej doświadczeń. W konkluzji trzydniowego spotkania uczestnicy zgodnie stwierdzili, że nie jest to jednak łatwe. Podkreślali stopień skomplikowanej wojennej materii w sferze faktografii, a także jej wykorzystania w nowej rzeczywistości społeczno-politycznej, którą nie tak sobie wyobrażano w 1945 r.

Konferencja przyniosła możliwość skonfrontowania tez głoszonych przez historyków wojskowości z doświadczeniem tzw. pola walki reprezentowanym przez obecnych licznie oficerów Wojska Polskiego. W żołnierskich kuluarach słyszało się głosy, że była to świetna lekcja historii, z której wyniesiono wiele cennych wniosków. Jednocześnie oficerowie stwierdzili, że brak jednolitej wykładni wydarzeń II wojny światowej bardzo utrudnia w wojsku odwoływanie się do polskich tradycji wojskowych. Ich zdaniem konferencja pomogła wypracować nowe spojrzenie, które pozwalało na wyciąganie praktycznych i realnych wniosków z tego trudnego okresu nieodległej rzeczywistości. Wojskowi zaakcentowali potrzebę podniesienia poziomu wiedzy związanej z historią wojskowości poprzez nawiązanie kontaktów z profesjonalnymi historykami wojskowości, nie tylko w formie tego typu konferencji, ale bezpośrednio w jednostkach wojskowych.

Program konferencji łączył ze sobą sprawy merytoryczne z elementami rekreacyjnymi. Organizatorzy umiejętnie wpisali w czas trzydniowego spotkania ogląd miejsc historycznych i atrakcyjnych przyrodniczo. Świadomy wybór na miejsce obrad Węgorzewa okazał się strzałem w „dziesiątkę”, gdyż jest to miejsce, w którym oba światowe konflikty zbrojne, a zwłaszcza II wojna światowa, szczególnie odcisnęły swoje piętno: począwszy od wybudowania przez Niemców stanowisk dowodzenia szczebla centralnego III Rzeszy, przez bliskość nowej granicy ustanowionej w wyniku decyzji alianckich na konferencjach jałtańskiej i poczdamskiej, skończywszy na przymusowych wysiedleniach Niemców i ludności autochtonicznej oraz przesiedleniach na ich miejsce Polaków i Ukraińców. Organizatorzy gwarantowali dobrą pogodę i piękne krajobrazy. Słowa dotrzymali. Było to tym bardziej istotne, że już pierwszego dnia uczestnicy konferencji mieli możliwość w ramach podróży historyczno-wojskowej skonfrontować wiedzę z rzeczywistością odnoszącą się do rozmieszczenia i funkcjonowania stanowisk dowodzenia szczebla centralnego III Rzeszy w Mamerkach na Mazurach z lat 1941-1944. Dzień drugi naukowego spotkania zakończy- 
ła podróż historyczno-wojskowa do kwatery Himmlera w Pozezdrzu Giżycku oraz podróż statkiem mazurskimi kanałami i szlakami jezior Niegocin i Kisajno. Przy zwiedzaniu schronów w Pozezdrzu padła deklaracja zorganizowania w przyszłym roku, w 50 rocznicę śmierci gen. dyw. Tadeusza Bora-Komorowskiego, konferencji poświęconej temu wybitnemu Polakowi i żołnierzowi oraz spopularyzowania faktu więzienia generała w tym miejscu bezpośrednio po upadku Powstania Warszawskiego.

Organizatorzy zapewnili uczestników konferencji, że jej efektem końcowym w wymiarze naukowym będzie publikacja. Ponadto, wnioski z dyskusji zostaną wykorzystane w bieżącej pracy naukowej a także przekazane do wykorzystania dowództwu Wojska Polskiego i poszczególnym ośrodkom wojskowego szkolnictwa wyższego.

$\mathrm{Na}$ koniec wypada zauważyć, że uczestnicy konferencji zostali zakwaterowani w komfortowych warunkach w ośrodku wypoczynkowym Góra Wiatrów niedaleko Trygortu w pobliżu Węgorzewa. Kwestie organizacyjne stały na najwyższym poziomie. Gwoli ścisłości należy dodać, że konferencja została zorganizowana dzięki wsparciu finansowemu Urzędu Marszałkowskiego Województwa Warmińsko-Mazurskiego i Muzeum Wojsk Lądowych w Bydgoszczy. 